\title{
"Bai Niao Chao Feng": Artisan Spirit and Elegy
}

\author{
Sun Pingping \\ Collage of Humanism, Weinan Normal University, Weinan, Shaanxi, 714099
}

Keywords: Bai niao chao feng, Wu Tianming, Artisan Spirit

\begin{abstract}
The movie "Bai Niao Chao Feng" (Song of the Phoenix) is Wu Tianming's posthumous masterpiece. He used the traditional artistic techniques, adhered to his own artistic ideal in the current film market, expressed by the suona as the representative of the traditional folk culture existence concerns. In the film, Jiao Sanye, a master of suona, spared no efforts in inheriting this folk art heritage. There is a common spiritual core among them, namely, a craftsman spirit based on love, striving for perfection, persistence and dedication.
\end{abstract}

\section{Introduction}

"Bai niao chao feng" is directed by Wu Tianming following the "chief executive" 10 years after the re directed work. The August 2012 film shot, before release have been participating in Busan International Film Festival, the Hongkong International Film Festival, Tokyo Film Festival, and won the twenty-ninth China Golden Rooster Award Jury Prize, France tours Film Festival audience favorite film award, the thirteenth spiritual civilization construction of five project "award, the twentieth Beijing Student Film Festival awards, the first Silk Road International Film Festival Best Film Award and other awards [1-2]. However, due to the delayed issuance of funds, until May 6, 2016, after two years of Wu's death, the film was finally released on the nine line of the court on the side of Fang Li's efforts. But after the release, the volume is very low. In May 12th, after the producer Fang in the live in passion, kneel, "bai niao chao feng" from the rate of less than 4/1000 was up to eleven percent, the attendance is very good. Since then, around the film and the formation of the "phenomenon" of the event, its topic and the public opinion has been far beyond the film itself [3]. The spirit of dedication to the movie art and director Wu Tianming success in the film industry to known as the film master, the love between art and film in Simon of folk suona and heritage, with the spirit of the common core, which is a love based "excellence", "persevere" and "focus and dedication" artisan spirit.

\section{The Film Adaptation of Prominent Focal Simon, Enhance the Sense of Tragedy}

The movie "bai niao chao feng" is based on the Guizhou youth writer Xiao Jianghong's novel of the same name, a description of the Guizhou Xiuwen County folk Suona music class two generation suona artists and the folk art form in modern extrusion is gradually disappearing. Director Wu Tianming in the adaptation, the story moved to his familiar in the countryside of Shaanxi Province, the main characters, the plot basically follows the original, only slightly in the character shaping adjustment [4]. In the novel Tian Ming's father and master respectively as the older generation of Tianming amusement and appreciation of traditional suona performer, is basically equal; in the film, he apparently became the center of the focal character of the story, her father had occurred in the tour plot he was grafted to coke. This adjustment film's meaning is very obvious, all the efforts and dedication will adhere to the core of narrative by suonaqu "bai niao chao feng" gradually disappear in the folk to suona artists Simon mentoring for coke folk heritage of the suona art, the story of the emotional tone by helpless sad and hard turning. It is through this film director Wu Tianming's expression of the tide of market tide under the impact of the decline of traditional folk culture of concern, expression of commercial culture pervasive idea of the film art, the film itself is the director of feelings and words for [5-6].

Fine-tuning of the story in the film highlights the adherence of Jiao Banzhu to suona skills and 
enhance the film's tragedy. In the original days of Ming's father was dying on the occasion, entrust a house to sell cattle swim Tianming with suona gear; father buried swim forever love in the suona, as travel home class troupe the son of even the most basic four also did not give his father together and in the father's grave memorial plot. In the film, the protagonist replacement coke troupe [7]. The other in the sinus old party's funeral, writes of the old party to enjoy this sinus of noble character and high prestige can swim, but we look forward to watching Tianming said he forgot. The master turned angrily broken suona and disappears in the night, for the film adaptation of Tian Ming to be blown, to adhere to the master playing until the blood coma, this is the film most viewers touching scene. The original master finally left the countryside to see the door in the sapphire carton factory, completely abandoned the suona art, and film, sapphire is engaged in the restoration of ancient buildings, and the coke master died in regret and frustration in the end, which backs away forever fixed in the audience's mind [8]. If the original in the death of his father, the master forsook the work gives people a sense of desolation, director $\mathrm{Wu}$ Tianming adapted master playing hematemesis, laid the dying entrust film tragic tone. The film adaptation of the suona he strengthened the coke's image, focusing on the suona as the representative of the traditional folk cultural inheritance in the embarrassing situation.

\section{3. "Bai Niao Chao Feng" the Cultural Metaphor}

This is a very rich cultural connotation. It was a folk story telling the Phoenix that the other birds stored a lot of food in silence while the other birds were playing. When the forest drought contributed to save the birds, the birds have pulled out a feather in their most beautiful clothes to make hundreds of birds and bird King enshrined her Phoenix, Phoenix every birthday, birds from all sides came to congratulate. Because of its beautiful implication of various forms of art creation become capture material, either the picture or point to the Suona music, to pursue the moral [9]. For example, this song to warm and cheerful melodies show the harmony of nature full of vigour, in Henan, was used in the wedding ceremony, of good fortune and happiness; the folk picture conveys, stability and harmony, good weather, a bumper grain harvest people live and work in peace and contentment, the wind Qing Zheng Ming scene in a time of national peace and order.

Director Wu Tianming around this structure story, its meaning is very rich. First of all, this is China folk music classical repertoire, suona is strong folk wind instruments China has a long history, popular, rich and expressive skills. Its pronunciation is cheerful, bold and bold, loud and clear. It is one of the most popular and popular national musical instruments in the gang. It is widely used in folk wedding, funeral, marriage, marriage, ritual, music, ceremony, and Yangge. Suona classic tracks in folk spread and adaptation and singing skills blowing suona for thousands of years of tradition, the rich folk culture infiltration. Historically, truly Suona music survival soil culture, which is mainly to weddings and funerals folk activities. Suona music has actually become a part of the folk activities, is closely related to the relationship between the two. Secondly, because suonaqu attached to the rich folk culture, therefore, it has a relationship with traditional cannot bear to part from each other and etiquette. The director will be transplanted to the story by the Guizhou rural areas in the countryside of Shaanxi Province, "bai niao chao feng" is as the main instrument to suona song [10-11]. The master will teach it to a disciple of skills and good character, suona band in order to "ban" in the form of travel service in the town near the Hamlet, weddings and funerals, in the local funeral suona playing is divided into two units, four units, eight Taiwan and bai niao chao feng, playing what level, not according to the how many home owners pay, not according to how many classes suona hands, is made according to the deceased as suona troupe, merit and virtue. To some extent, in addition to entertain the crowds, suona playing in the funeral for the dead bear the final judgement function, moral mediocrity blowing two units, four units of secondary blowing, blowing the superior eight Taiwan, and "bai niao chao feng" is the only respectable person to enjoy the blessing.

In addition, the suona troupe in addition to playing skill, but also highly for fan, in order to uphold justice at the funeral, with authority in the villagers in. In the film but in the choice of coke future successor, bai niao chao feng is very cautious. He chose the general nature of talent but 
honest, diligent sureness of the tour Tianming and give up the talented, and mind essential sapphire. This film still discusses the relationship between music and etiquette for thousands of years before Confucius proposed, the role of education in music, especially the more normative role in the ritual music of the ritual. In the film, he begged for coke to check home filial sons with forty years of age, check the old Mr. playing bai niao chao feng, coke master unmoved, on the side of the disciple said: "this is not a question of money, do you know how to check the home is bigger? Because when he was the village head, he squeezed the other four surnames [12-13]. "While the coke master, is not only a clean and diligent heart to treat craft craftsman, is called the Confucian scholar, hold on to rural villagers shared values, as a ruler, measure the funeral master as before. With the comments on selected Rodney specifications in this 100 gathered public funeral ceremony way, Rodney is where the country order and centripetal force."

\section{Wu and Coke Simon: Ingenuity Carpenter Love}

"Bai niao chao feng" as Wu Tianming's last work, with all his efforts and Thoughts on life and society, in the film completed a month after making clip, Wu Dao died. Because of the lack of Xuanfa fee, the film has been shelved; the twists and turns, and finally in May 6, 2016 to meet with the audience. Around the film and the public opinion, to construct a film than the text itself more dramatic contrast between the film's story, the pure artistic pursuit and mercenary market, also caused a lot of discussion. At the same time, as a representative figure of the fourth generation of directors, Wu guide belongs to the lens language of the generation directors, that is, the non-popular image narration and the following artistic concepts are more obvious in the movie. The film has become the fourth generation director of innuendo: the film in the film market situation exactly with the fourth generation of director to film the spirit of the art experience.

He is the guide to Wu Jiao expressing role. In the film, he is a focal suona suona art, is adhere to the inheritor, director Wu Tianming is the art master, he dedicated to his own artistic spirit and faith, patient, ten years of grinding a grind. He burnt to the apprentice teach skills when said: "we are a suona work, is a job, someone must take responsibility." Only the bones of the suona blowing to the people, to fight the suona pass." Director Wu Tianming once said, "I love movies, and I've only done this all my life." He did not make a film for the money, and took what he really wanted to do. The daughter questioned "bai niao chao feng" when he said: "I don't take this film for the present audience, but I want to leave it to the future ". He took action to defend the dignity of the film creation. In the way of creation, Wu guided the "experience life, the discussion of the script" as the "compulsory course" of the actor, following the traditional realism [14]. Wu guide project itself as a "cultural Wake" image, "he almost coke was directed by Wu Tianming himself and reflexive". As China Federation vice president Zhong Chengxiang said; "to a certain extent, we can say "bai niao chao feng" in the coke image is Simon Wu Tianming; he can say in the coke image at least, casting a Wu Tianming on life, art and film deep insights, casting him understanding and inheriting the excellent traditional culture of the Chinese nation the truth, casting the flesh with his figure in the bottom." Wu guide from the "life" (1984), "patio" (1988), its focus has never left the masses in the process of modernization, did not leave in the economy in the mighty wave crashing on a sandy shore of the "human" questioning, never give up to the movie art dedicated to adhere to. Some critics have control of "life", "bai niao chao feng", argues that the former is of "feudal" narrative criticism, expression of the modern value of the pursuit of personal liberation view; while the latter is the power of construction for the maintenance of social order of the positive force of rural life. Whether it is a criticism or affirmation of traditional ethics, director Wu Tianming is based on the current social and cultural environment of China, and he makes artistic creation from the perspective of human nature [15]. His works have never left the attention of the people, the attention to the times, the concern of the Chinese tradition and the concern of the national culture. As he said in the film, he will blow suona to the bone, the reality of the Wu guide was a movie with soul and heart. 


\section{Acknowledgements}

This paper is grateful for its support from the fund project: the key research base of philosophy and social sciences of Shaanxi Provincial Department of Education: the support of film and Television Communication Research (17JZ030) of Qin and Dong's historical and cultural resources.

\section{References}

[1] Tanaka K, Ikeda K, Yamasaki T, et al. Elaborate designs with artisan spirit to treat liver cancer in Japan [J]. Kanzo, 2012, 53(8):463-485.

[2] Yang H. On the Solemn and Stirring Harmony Between Man and Nature in Moby-Dick [J]. Journal of Hunan City University, 2010, 6(4):1-24.

[3] Maccabe C, Warner R, Murray K. True to the spirit: film adaptation and the question of fidelity [J]. Literature Film Quarterly, 2012, 37(2):239-241.

[4] Chong E K M. Beyond birdsongs and the five notes: Teaching with Wang Jianzhong's Bai Niao Chao Feng[C]// International Society for Music Education Conference. 2009.

[5] Estrada G S. Two-spirit film criticism: Fancydancing with Imitates Dog, Desjarlais and Alexie [J]. Post Script, 2010, 29(:3).

[6] Li P, Ducheyne P. Quasi-biological apatite film induced by titanium in a simulated body fluid.[J]. Journal of Biomedical Materials Research Part A, 2015, 41(3):341-348.

[7] Cook W J, Felderman E J. Reduction of data from thin-film heat-transfer gages - A concise numerical technique. [J]. Aiaa Journal, 2015, 4(3):561-562.

[8] Dona J M, Herrero J. ChemInform Abstract: Process and Film Characterization of Chemical-Bath-Deposited ZnS Thin Films. [J]. Cheminform, 2015, 25(15):205-210.

[9] Li Q, Luo G, Feng J. Direct Electron Transfer for Heme Proteins Assembled on Nanocrystalline TiO2 Film [J]. Electroanalysis, 2015, 13(5):359-363.

[10] Wang P, Yu-Tao F U, Xiang W. Analysis on the Style and Characteristics of Chinese Piano Music "Bai Niao Chao Feng"[J]. Journal of Sichuan College of Education, 2011.

[11] Choi C, Lin L, Liu Y, et al. Flexible Optical Waveguide Film Fabrications and Optoelectronic Devices Integration for Fully Embedded Board-Level Optical Interconnects [J]. Journal of Lightwave Technology, 2015, 22(9):2168-2176.

[12] Ehret D L, Ho L C. The effects of salinity on dry matter partitioning and fruit growth in tomatoes grown in nutrient film culture. [J]. Journal of Pomology \& Horticultural Science, 2015, 61(3):361-367.

[13] EKM Chong. Beyond Birdsongs and the Five Notes: Teaching with Wang Jianzhong's "Bai Niao Chao Feng"

[14] Poynton C A. SMPTE Tutorial: “Gamma” and its Disguises: The Nonlinear Mappings of Intensity in Perception, CRTs, Film, and Video [J]. Smpte Journal, 2015, 102(12):1099-1108.

[15] Somasundaram S, Chenthamarakshan C R N, Tacconi N R D, et al. Photocatalytic production of hydrogen from electrodeposited p-Cu2O film and sacrificial electron donors [J]. International Journal of Hydrogen Energy, 2015, 32(18):4661-4669. 